\title{
EFEKTIFITAS MODEL PEMBELAJARAN KOOPERATIF TIPE STUDENT TEAMS ACHIEVEMENT DIVISION (STAD) TERHADAP KETERAMPILAN BERHITUNG PECAHAN KELAS IVB MIN NGLAWU SUKOHARJO
}

\author{
Warsito \\ Madrasah Ibtidaiyah Negeri Nglawu Sukoharjo \\ e-mail : Warsito.syafiq07@gmail.com
}

\begin{abstract}
This study aims to determine: Effectiveness of the STAD type cooperative learning model on fraction counting skills in IVC class 2016/2017 academic year. This research is experimental research. with the design of the One Group Pretest Potest Design. The research sample was obtained from all class students of class IVB MIN Nglawu Sukoharjo totaling 38 students consisting of 23 male students and 15 female students .. The sampling technique in this study was total sampling. The technique of collecting data uses a fraction counting skill test. Test the validity of the data using the item analysis test using Anates. Data analysis techniques in this study are t-test and N-gain test. In this study analyzed with the help of SPSS 21 software $t$ test and $\mathrm{N}$-gain test.The result of calculating the value of " $t$ " is equal to - 15,989 with sig (2tailed) equal to 0,000 whose value is less than 0.05 . It can be concluded that there are significant differences in fraction counting skills before and after using the STAD type cooperative learning model. The results of the calculation of effectiveness using the $\mathrm{N}$-gain formula are 0.427 , if it is confirmed by the effectiveness criteria and the results fall into the criteria of being.
\end{abstract}

Key words: Effectiveness, Learning Model

\begin{abstract}
Abstrak
Penelitian ini bertujuan untuk mengetahui: Efektifitas model pembelajaran kooperatif tipe STAD terhadap keterampilan berhitung pecahan kelas IVC Tahun ajaran 2016/2017. Penelitian ini adalah penelitian eksperimen. dengan desain One Group Pretest Potest Design. Sampel penelitian ini didapat dari seluruh siswa kelas siswa kelas IVB MIN Nglawu Sukoharjo berjumlah 38 siswa yang terdiri dari 23 orang siswa laki-laki dan 15 orang siswa perempuan.. Teknik sampling dalam penelitian ini adalah total sampling. Teknik pengumpulan data menggunakan tes keterampilan berhitung pecahan. Uji validitas data menggunakan uji analisis butir soal menggunakan Anates. Teknik analisis data dalam penelitian ini adalah uji t dan uji $\mathrm{N}$-gain. Dalam penelitian ini di analisis dengan bantuan software SPSS 21 uji t dan uji Ngain.Hasil perhitungan nilai " $t$ " adalah sebesar - 15,989 dengan sig (2-tailed) sebesar 0,000 yang nilainya kurang dari 0,05 . Hal ini dapat disimpulkan bahwa ada perbedaan signifikan keterampilan berhitung pecahan sebelum dan sesudah menggunakan model pembelajaran kooperatif tipe STAD Hasil perhitungan efektifitas menggunakan rumus $\mathrm{N}$-gain sebesar 0,427, apabila dikonfersikan dengan kriteria keefektifan dan hasil tersebut masuk dalam kriteria sedang.
\end{abstract}

Kata Kunci: Efektifitas, Model Pembelajaran

\section{PENDAHULUAN}

Pendidikan disuatu negara dapat menggambarkan kemajuan dari negara tersebut. Keberhasilan pengelolaan pemerintah bidang pendidikan dapat tercermin dari kualitas gurunya. Guru menjadi kunci pokok dan sangat mempunyai andil besar dalam menentukan nasib bangsa sehingga tuntutan untuk menjadi guru pun semakin sulit. Salah satu kompetensi yang wajib dimiliki seorang guru iyalah kompetensi profesional. Kompetensi profesional ini tidak saja harus dimiliki guru di sekolah menengah, melainkan juga wajib dimiliki guru di sekolah dasar maupun guru di pendidikan anak usia dini. Tetapi kenyataanya 
salah satu permasalahan pendidikan yang dihadapi oleh bangsa Indonesia merupakan rendahnya mutu proses kegiatan belajar mengajar pada setiap jenjang satuan pendidikan, terkhusus pada jenejang pendidikan dasar. Jenjang sekolah dasar merupakan tempat pendidikan yang menyelenggarakan program pendidikan enam tahun bagi anak-anak yang telah menyelesaikan pendidikan pada jenjang pendidikan anak usia dini. Pada jenjang inilah pembelajaran bermakna melalui pembelajaran berkelompok dapat menjadi alternatif mengoptimalkan proses dan hasil pembelajaran. Diantara banyak mata pelajaran, pada umumnya yang menjadi momok siswa sekolah dasar / Madarasah Ibtidaiyah adalah mata pelajaran matematika. Menurut Marsigit (2008: 9) bahwa karakteristik Matematika tergantung dari jenis Matematika, apakah Matematika murni, Matematika terapan, atau Matematika sekolah. Ebbutt dan Straker (dalam Marsigit 2008: 9) mendefinisikan tentang Matematika sekolah yang selanjutnya disebut dengan Matematika. Matematika merupakan suatu kegiatan, kegiatan tersebut antara lain : 1 . Kegiatan penelusuran pola dan hubungan, 2. Kreativitas yang memerlukan imajinasi, intuisi dan penemuan, 3. Kegiatan problem solving, dan 4. Alat untuk berkomunikasi. Jika seorang guru tidak bisa memilih strategi, model, metode dan media pembelajaran dengan tepat sesuai dengan karakteristik siswa maka hampir dipastikan proses dan hasil belajar siswa tidak maksimal. Hal ini juga terjadi di MIN Nglawu pada materi keterampilan berhitung pecahan di kelas IVB, siswa merasa kesulitan dengan materi tersebut, sehingga guru harus mencari inovasi untuk membelajarkan secara efektif dan efisien.

Penggunaan model pembelajaran kooperatif bisa dijadikan salah satu bentuk upaya untuk meningkatkan proses dan hasil belajar. Karakteristik model pembelajaran kooperatif menurut Nur Asma (2006: 11) adalah sebagai berikut:(1) Peserta didik dalam kelompok secara kooperatif menyelesaikan materi belajar sesuai kompetensi dasar yang akan dicapai, (2) Kelompok dibentuk dari beberapa peserta didik yang memiliki kemampuan berbeda-beda, baik tingkat kemampuan tinggi, sedang, dan rendah, (3) Penghargaan lebih menekankan pada kelompok daripada masing-masing individu, (4) Dalam pembelajaran kooperatif dikembangkan diskusi dan komunikasi dengan tujuan agar peserta didik saling berbagi kemampuan, belajar berpikir kritis, menyampaikan pendapat, memberi kesempatan menyalurkan kemampuan, saling membantu belajar, saling menilai kemampuan dan peranan diri sendiri maupun teman lain.

Dengan suasana pembelajaran berkelompok banyak hal positif yang akan didapatkan siswa, terutama tipe Student Teams Achievement Division (STAD). Model Kooperatif tipe ini merupakan pembelajaran aktif yang menuntut siswa untuk berpartisipasi pada saat proses pembelajaran berlangsung. (Agus Suprijono, 2011: 111). Model pembelajaran aktif pada dasarnya suatu model pembelajaran yang mengarahkan atensi peserta didik terhadap materi yang dipelajarinya Robert E.Slavin dalam (Narulita, 2012: 11) menjelaskan bahwa dalam model pembelajaran kooperatif tipe STAD, para siswa dibagi dalam tim belajar yang terdiri atas empat orang yang berbeda-beda tingkat kemampuan, jenis kelamin, dan latar belakang etniknya. Guru menyampaikan pelajaran, lalu siswa belajar dalam tim mereka untuk memastikan bahwa semua anggota tim telah menguasai pelajaran. Selanjutnya semua siswa mengerjakan kuis mengenai materi secara sendiri-sendiri, dimana saat itu mereka tidak diperbolehkan untuk saling membantu. Trianto (2011: 52-53) persiapan-persiapan untuk pembelajaran tersebut antara lain: (1) Perangkat Pembelajaran, (2) Membentuk Kelompok Kooperatif, (3) Menentukan Skor Awal, (4) Pengaturan Tempat Duduk, (5) Kerja Kelompok.

\section{METODE PENELITIAN}

Penelitian ini adalah penelitian eksperimen. dengan desain One Group Pretest Potest Design. Pada model ini dilakukan pretest untuk mengukur ketrampilan berhitung pecahan siswa sebelum di terapkan model pembelajaran kooperatif tipe STAD kemudian baru di lakukan postest 
sehingga dapat diketahui perbedaanya. (Sukardi, 2010:180-181). Sampel penelitian ini didapat dari seluruh siswa kelas siswa kelas IVB MIN Nglawu Sukoharjo berjumlah 38 siswa yang terdiri dari 23 orang siswa lakilaki dan 15 orang siswa perempuan.. Teknik sampling dalam penelitian ini adalah total sampling. Teknik pengumpulan data menggunakan tes keterampilan berhitung pecahan. Uji validitas data menggunakan uji analisis butir soal menggunakan Anates. Teknik analisis data dalam penelitian ini adalah uji t dan uji $\mathrm{N}$-gain. Dalam penelitian ini di analisis dengan bantuan software SPSS 21 uji t dan uji $\mathrm{N}$-gain.

\section{HASIL DAN PEMBAHASAN}

Data hasil keterampilan berhitung pecahan siswa diperoleh dari instrumen yang dibuat berupa instrumen tes keterampilan berhitung pecahan. Perbandingan hasil antara sebelum/pretest dan sesudah/posttest menggunakan model pembelajaran kooperatif tipe STAD.

Tabel 1. Diskripsi pretest dan postest

\begin{tabular}{|c|c|c|c|c|c|c|c|}
\hline \multirow{2}{*}{ Interval } & \multicolumn{2}{|c|}{ Sebelum } & \multirow{2}{*}{$\begin{array}{c}\text { Uku } \\
\text { ran } \\
\text { Pem } \\
\text { usat } \\
\text { an \& } \\
\text { Peny } \\
\text { ebar } \\
\text { an }\end{array}$} & \multirow{2}{*}{ Interval } & \multicolumn{2}{|c|}{ Sesudah } & \multirow{2}{*}{$\begin{array}{c}\text { Ukura } \\
\text { n } \\
\text { Pemus } \\
\text { atan \& } \\
\text { Penye } \\
\text { baran }\end{array}$} \\
\hline & $\mathbf{F i}$ & $\begin{array}{c}\text { Frekue } \\
\text { nsi } \\
\text { Relatif } \\
(\%) \\
\end{array}$ & & & $\mathbf{F i}$ & $\begin{array}{c}\text { Frekue } \\
\text { nsi } \\
\text { Relatif } \\
(\%) \\
\end{array}$ & \\
\hline $90<$ & 0 & 0,0 & & $90<$ & 2 & 5,2 & \\
\hline $\begin{array}{l}61- \\
90\end{array}$ & 2 & 5,2 & $\underset{43,3}{X}=$ & $\begin{array}{c}61- \\
90\end{array}$ & 28 & 73,7 & $X=$ \\
\hline $\begin{array}{l}30- \\
60\end{array}$ & 30 & 78,9 & $\mathrm{~s}=$ & $\begin{array}{l}30- \\
60\end{array}$ & 8 & 21,1 & $\begin{array}{c}67,44 \\
\mathrm{~s}=8,76\end{array}$ \\
\hline$<30$ & 6 & 15,9 & 9 & $<30$ & 0 & 0,0 & \\
\hline $\begin{array}{l}\text { Jum } \\
\text { lah }\end{array}$ & 38 & 100,00 & & $\begin{array}{c}\text { Juml } \\
\text { ah }\end{array}$ & 38 & 100,00 & \\
\hline
\end{tabular}

Tabel 2. Diskripsi Statistik hasil SPSS Descriptive Statistics

\begin{tabular}{|l|c|c|c|r|r|}
\hline & N & $\begin{array}{c}\text { Minim } \\
\text { um }\end{array}$ & $\begin{array}{l}\text { Maxi } \\
\text { mum }\end{array}$ & Mean & Std. Deviation \\
\hline Pretest & 38 & 20,00 & 79,00 & 43,394 & 12,29489 \\
Posttest & 38 & 50,00 & 91,00 & 67,447 & 8,76324 \\
$\begin{array}{l}\text { Valid N } \\
\text { (listwise) }\end{array}$ & 38 & & & 4 & \\
\hline
\end{tabular}

Perbandingan keterampilan berhitung pecahan siswa sebelum dan sesudah menggunakan model pembelajaran kooperatif tipe STAD dapat dilihat pada gambar.

\section{Pretest}

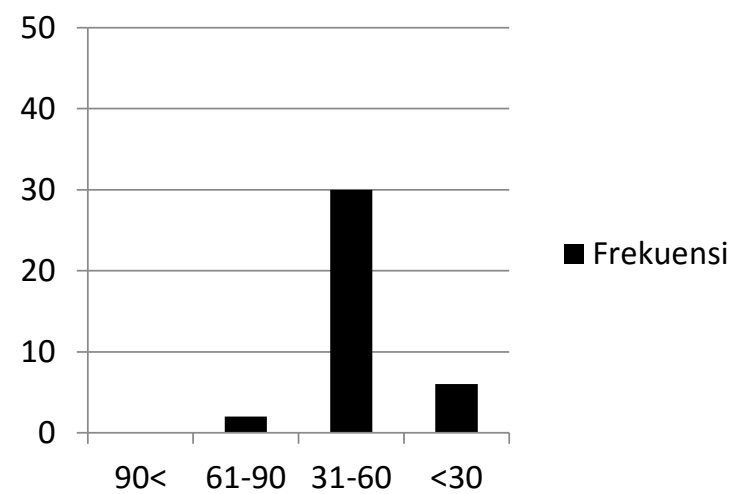

Gambar 1. Pretest

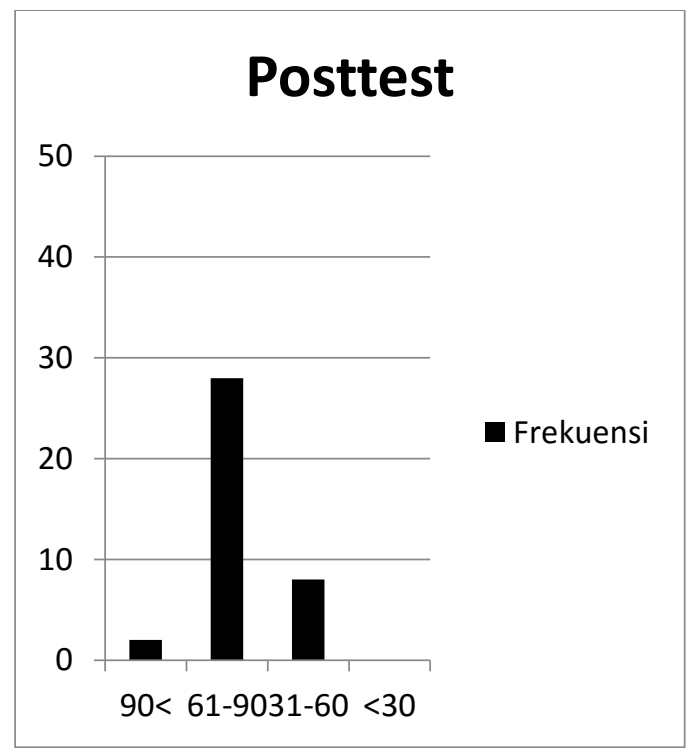

Gambar 2. Postest

Data hasil keterampilan berhitung pecahan siswa sebelum dan sesudah menggunakan model pembelajaran kooperatif tipe STAD selanjutnya dianalisis menggunakan uji-t tepatnya dengan uji Paired Sample T-test. Hasil perhitungan nilai "t" 
adalah sebesar - 15,989 dengan sig (2-tailed) sebesar 0,000 yang nilainya kurang dari 0,05. Hal ini dapat disimpulkan bahwa ada perbedaan signifikan keterampilan berhitung pecahan sebelum dan sesudah menggunakan model pembelajaran kooperatif tipe STAD.

Tabel 3. Hasil SPSS untuk uji Paired Sample T-test

Paired Samples Test

\begin{tabular}{|c|c|c|c|c|c|c|c|c|}
\hline & \multicolumn{5}{|c|}{ Paired Differences } & \multirow[t]{2}{*}{$\mathrm{t}$} & \multirow[t]{2}{*}{$\mathrm{df}$} & \multirow{2}{*}{$\begin{array}{l}\text { Sig. } \\
(2- \\
\text { taile } \\
\text { d) }\end{array}$} \\
\hline & \multirow[t]{2}{*}{$\begin{array}{l}\mathrm{Me} \\
\text { an }\end{array}$} & \multirow[t]{2}{*}{$\begin{array}{l}\text { Std. } \\
\text { Devi } \\
\text { ation }\end{array}$} & \multirow[t]{2}{*}{$\begin{array}{l}\text { Std. } \\
\text { Error } \\
\text { Mean }\end{array}$} & \multicolumn{2}{|c|}{$\begin{array}{c}95 \% \\
\text { Confidence } \\
\text { Interval of } \\
\text { the } \\
\text { Difference }\end{array}$} & & & \\
\hline & & & & $\begin{array}{c}\text { Lowe } \\
\mathrm{r}\end{array}$ & $\begin{array}{l}\text { Up } \\
\text { per }\end{array}$ & & & \\
\hline $\begin{array}{ll} & \text { Pre } \\
\text { P } & \text { test } \\
\text { a } & - \\
\text { ir } & \text { Po } \\
1 & \text { stte } \\
& \text { st }\end{array}$ & $\begin{array}{r}- \\
24 \\
052 \\
63\end{array}$ & $\begin{array}{r}9,273 \\
47\end{array}$ & $\begin{array}{r}1,504 \\
35\end{array}$ & $\begin{array}{r}- \\
27,10 \\
074\end{array}$ & $\begin{array}{r}- \\
21, \\
004 \\
52\end{array}$ & $\begin{array}{r}- \\
15 \\
989\end{array}$ & 37 & ,000 \\
\hline
\end{tabular}

Hasil perhitungan efektifitas menggunakan rumus $\mathrm{N}$-gain $(\langle\mathrm{g}\rangle=($ Skor Post Test $)-$ (Skor Pre Test) / (Skor Maksimum) - (Skor Pre Test) ) yaitu sebesar 0,427, apabila dikonsultasikan dengan kriteria keefektifan dan hasil tersebut masuk dalam kriteria sedang. Artinya keefektifan dari penggunaan model pembelajaran kooperatif tipe STAD terhadap keterampilan berhitung pecahan siswa termasuk dalam kriteria sedang. Dari kedua hasil uji baik uji-t maupun uji N-gain dapat disimpulkan bahwa model pembelajaran kooperatif tipe STAD efektif dalam meningkatkan keterampilan berhitung pecahan. Hasil ini sesuai dengan Trianto (2011: 26), model pembelajaran kooperatif dapat meningkatkan hasil belajar yang berupa keterampilan akademik dan sosial. Ibrahim, dkk memaparkan tujuan pembelajaran kooperatif mencakup tiga, yaitu hasil belajar akademik, penerimaan terhadap keragamaan, dan pengembangan keterampilan sosial. Dalam model pembelajaran kooperatif tipe Student Teams Achievement Division (STAD) ada tahapan pembentukan kelompok. Pembentukan kelompok, guru membagi siswa berkelompok secara heterogen yang terdiri dari berbagai tingkat kemampuan, jenis kelamin, dan latar belakang suku. Pada pembelajaran ini memberikan keuntungan pada siswa kelompok bawah dan kelompok atas yang bekerja bersama menyelesaikan tugas-tugas akademik. Mereka akan bekerjasama dalam menyelesaikan tugas akademik, saling membantu memahami konsep-konsep yang sulit, dan membantu siswa menumbuhkan kemampuan berpikir kritis.

\section{KESIMPULAN}

Dari pengujian penelitian didapatkan hasil bahwa ada perbedaan keterampilan berhitung pecahan siswa sebelum dan sesudah menggunakan model pembelajaran kooperatif tipe STAD. Hasil perhitungan nilai "t" adalah sebesar - 15,989 dengan sig (2-tailed) sebesar 0,000 yang nilainya kurang dari 0,05 . Hal ini dapat disimpulkan bahwa ada perbedaan signifikan keterampilan berhitung pecahan siswa sebelum dan sesudah menggunakan model pembelajaran kooperatif tipe STAD. Hasil uji efektifitas menggunakan rumus Ngain didapatkan angka sebesar 0,427 yang artinya keefektifan dari media tersebut berada pada kriteria kefektifan sedang.

\section{SARAN}

Berdasarkan hasil yang dicapa, peneliti memberikan saran sebagai berikut:

a. Model pembelajaran kooperatif tipe STAD dapat menjadi pilihan untuk diterapkan di mata pelajaran lain sehingga proses dan hasil belajar dimungkinkan menjadi lebih baik.

b. Dilakukanya penelitian lanjutan mengenai model pembelajaran kooperatif tipe STAD pada ranah kognitif maupun afektif. 


\section{DAFTAR PUSTAKA}

Agus Suprijono. (2011). Cooperative Learning (Teori dan Aplikasi PAIKEM). Yogyakarta: Pustaka Pelajar

Andang Ismail. (2006). Education Games: Menjadi Cerdas dan Ceria dengan Permainan Edukatif. Yogyakarta: Pilar Media

Anita Lie. (2010). Cooperative Learning Mempraktikkan di Ruang-ruang Kelas. Jakarta: Grasindo.

Burhan Nurgiyantoro. (2012). Statistik Terapan untuk Penelitian Ilmu-Ilmu Sosial. Yogyakarta: Gadjah Mada University Press.

Etin Solihatin \& Raharjo. (2007). Cooperatif Learning Analisis Model Pembelajaran IPS. Jakarta: Bumi Aksara.

Herman Hudojo. (2005). Pengembangan Kurikulum dan Pembelajaran Matematika. Malang: UM Press.

Marsigit. (2008). Pengembangan Kompetensi Guru Matematika Melalui Model- Model Pembelajaran Lesson Study dan PTK Melalui Peningkatan Peran MGMP. Yogyakarta: FPMIPA UNY.

Sukardi. 2010. Metodologi Penelitian Pendidikan. Jakarta:Bumi Aksara

Trianto. (2011). Mendesain Model Pembelajaran Inovatif Progresif. Jakarta: Kencana. 